\title{
Academic Internship and Students' Satisfaction: Evidence from Greece
}

\author{
George Kipreos \\ Department of Sport Management \\ University of Peloponnese, Greece \\ Panagiotis Dimitropoulos \\ Department of Sport Management \\ University of Peloponnese, Greece
}

Received: May 22, 2016 Accepted: June 6, 2016 Published: August 1, 2016

doi:10.5296/jse.v6i3.9536 URL: http://dx.doi.org/10.5296/jse.v6i3.9536

\begin{abstract}
Internship is an educational activity which has the advantage of teaching students how to apply the knowledge and concepts they have acquired in the classroom thus achieving a thorough learning of the subject matter. The scope of this study is to examine the level of students' satisfaction from the internship program provided by the Department of Sport Management, University of Peloponnese in Greece. Questionnaire analysis was performed from a sample of students who have completed their internship and evidence revealed that $60 \%$ of respondents were satisfied with the internship program and more than $65 \%$ believe that the experiences gained from the internship will be significant for their future employment. Overall, students perceived the internship program as a significant feature of the curriculum and a mechanism that enhances future career potential.
\end{abstract}

Keywords: Internship, internship benefits, student's satisfaction, University of Peloponnese, Greece 


\section{Introduction \& theoretical background}

Internship programs have been incorporated into the curricula of the majority of academic institutions worldwide, in order to provide field experience opportunities to the students. According to Hergert (2009) and Khalil (2015), internship programs are provided on a basis of specific work hours that students must perform within an assigned institution, firm or organization, they are supervised by members of academic staff and a corporate counterpart and relative credits are awarded after the completion of the course. The goal of internship is to teach students how the real world operates. Teaching students how to apply the theoretical knowledge acquired in the classroom must be the ultimate goal of an academic institution (Khalil, 2015). According to Alpert et al. (2009), although students in the economic and business disciplines receive high quality education on theories, yet they lack significant initiative in solving business problems. This is the main reason why internship programs were incorporated in higher education institutions as a form of experiential learning procedure, filling the gaps in students' education and learning.

The introduction of internship program in academic institutions originated from the concept of service learning which according to Chambers (2009) involves a partnership between communities and academic institutions with educator determined learning experiences for students. According to Maynes et al. (2013), service learning improves the learning outcomes and for that reason it has been considered as an instructional strategy for deeper understanding of taught subjects. The benefits of service learning for students span from greater awareness of the links between theory and practice to social and environmental issues (Maynes et al., 2013).

Practically, the benefits of internship on the training, education and learning of students have been documented by several researchers in the field. Those benefits span from: self-fulfillment, productivity, teamwork, effective communication, critical thinking, technical skills and abilities or even social awareness and voluntarism (Khalil, 2015). Moreover, Alpert et al. (2009) documented that internship benefits students by closing the gap between learning and doing, improves employability, personal skills and professional development. Also, Clark (2003) pointed out that students with internship experiences can have career advantages in the form of choices, permanent employment or even remuneration. Binder et al. (2015) argue that internship yields greater perceived attractiveness of job applicants to recruiters and those graduates get a job more quickly and with higher salary in relation to their counterparts with no such experience. Also Binder et al. (2015) documented that the reason for the above-mentioned benefits of internship is the fact that those students with internship experience are better academic performers and improve their scores after they complete their internship position.

Furthermore, internship improves the students' personal skills and their adaptability to the working environment. Khalil (2015) provides evidence that students who completed their internship at Kuwait University gained better knowledge of the job market, enhanced some skills which they were not able to develop within the classroom (professionalism, team-playing capability, etc.) and finally improved their career potential since they were 
better prepared to adapt themselves to the work place upon graduation. Also, Andrews and Higson (2008) documented that skills relating to problem solving, critical thinking, self-confidence and even verbal communication were also enhanced for students with internship experience.

Nevertheless, internship does not only benefit students (who are the main target group in this case) but also organizations that accept interns within their labor force. Students can provide an edge on the daily operations of an organization since they bring novel ideas and offer some truthful and objective viewpoints for the business and the industry (Lee \& Chao, 2013). Also, interns can complete small projects that would be time consuming for regular employees, thus saving time and effort for other tasks. Moreover, Kwan (2005) argues that enterprises can select and recruit suitable student interns for permanent positions after their graduation, thus saving recruiting costs and other employment risks by selecting employees who have already proven their abilities and prospects. In addition, Maynes et al. (2013) argue that the benefits for host organizations include increased awareness on the benefits and values of post-secondary education and the development of partnerships with academic institutions that can lead to students' long term engagement with those organizations.

However, despite the fact that the benefits of internship have been proved by several researchers within different scientific fields, those benefits may not accrue if the internship programs are not carefully considered, assessed and organized. On the contrary, internships may result in disappointing experiences and outcomes for the students and the economy in general since Lee and Chao (2013) document that the negative experiences of students from the internship programs are significant determinants of students' decision to seek and accept a job position within the specific business sector. Consequently, students' opinion regarding the quality of the internship program and their satisfaction with the internship experience can be a significant input for academic institutions to help them improve their curricula and provide to their graduates access to the labor market.

Under this framework, the scope of this study is to examine how satisfied the students of the Department of Sport Management of the University of Peloponnese in Greece are with their internship experience and whether they gained any advantages for their future employability. The Department of Sport Management of the University of Peloponnese is the only academic unit in Greece offering a degree in Sport Management and the department's internship program is designed to provide experiential learning opportunities to students. The internship program has the form of a compulsory module which all students must attend in order to be eligible for graduation and receives six (6) credits for a two-month period during the summer.

However, since the inception of the internship program in 2006, there has not been a scientific analysis (using accepted methodologies) of the effectiveness of the program and how students perceive its usefulness for the improvement of their skills, knowledge and even employment opportunities. As Chambers and Chiang (2012) argue, satisfaction in terms of their academic experience is the most significant concern for students and academic institutions need to be aware of students' beliefs on this matter. According to Khalil (2015) and Chen et al. (2011), students perceive internship as beneficial when they have positive 
experiences, they have personal benefits and it has improved their employability. Thus, this study aims to fill a gap in the literature by providing ample evidence about the students' experience with the internship program and whether they perceived that they have received any of the abovementioned benefits of internship. This study is novel for the Greek academic environment since according to our knowledge there has been no other study examining intern satisfaction and experiences. Also, the current study can serve as a foundation for actions targeting the improvement of internship programs in the University of Peloponnese and other academic institutions in Greece.

The paper is organized as follows: The following section describes the details and specifics of the internship program of the Department of Sport Management, University of Peloponnese. The third section includes a discussion on the research method followed in this study and the data used in the analysis. The fourth section includes the results from the questionnaire analysis and the last section concludes the paper offering useful policy implications and directions for future research.

\section{Department of Sport Management internship program}

The internship program of the Department of Sport Management (University of Peloponnese) was initiated in 2006 with only a small fraction of students participating since there was a hesitation on behalf of sport organizations to accept interns due to the fact that the department was in its infancy and the market was not acquainted with is scope and contribution. The purpose of the internship program is the professional orientation and a first acquaintance of students with labor market conditions with issues related to the organization and management of sporting events and institutions. The students are able to apply the knowledge received in the theoretical courses in the field and this leads to the effective consolidation of the taught modules and the expansion of their knowledge regarding various aspects of sport management.

The internship program aims at preparing the Department's graduates and at enabling them to integrate smoothly into the labor market. Given the fact that the taught modules of the Department are highly interdisciplinary covering a very wide field of applications and since there is a clear lack of skilled man and women in the labor market that is able to design and oversee the implementation of integrated interventions in the field of sports management, students who are familiar with labor market conditions through the internship will strengthen their skills, their critical thinking and their employment chances in the near future. Based on the above, students will understand the importance of modern sports administration for the operation, performance and sustainability of sports organizations and businesses. In this way they will feel the importance of the scientific field of sports administration in order to claim their place in the labor market in Greece and abroad after their graduation.

To achieve the aforementioned goals every year a instructive seminar is conducted (as a workshop) by the supervisors / staff concerning: a) the condensed presentation of the theory associated with the objects of the internship (probably at similar groups of objects) and b) the orientation and characteristics of receiving organizations. Through the workshop the department aims largely to simulate actual working conditions in the host institutions. Then 
the students fill an application of interest for the department's internship office declaring the type of organization where they wish to perform their internship (local government or public organizations, corporations etc.) Then after a short interview and communication with the hosting organization, the students are allocated to the host organization and the implementation of the internship program actually begins and the progress is monitored constantly. In particular, each student assigned to cooperating organizations, is supervised by both a representative of each host institution and a member of academic staff who monitor the evolution of the process and the students' progress.

The internship program has the form of a compulsory module which all students must complete in order to be eligible for graduation. The length of the program is two months during the summer (July-August) with an award of six (6) credits (ECTS) and students are able to participate after completing the sixth semester of their studies. During those two months all interns are insured by the university and offered an indicative remuneration. Until recently, the number of cooperative (host) organizations has been 268. Seventy of them are public and local government organizations and the vast majority (198) are private organizations. From the private organizations more than $50 \%$ are operating within the sport and recreation sector and the rest of them are various service organizations. Finally, more than 200 students have participated and completed the internship program since its initiation (Kipreos \& Dimitropoulos, 2013).

Nevertheless, there has been no evidence through scientific methodology of the experiences of students and the perceived benefits from the program. The internship program (as any other academic educational activity) needs to be assessed and evaluated in terms of its quality and efficiency towards targeted goals and objectives (Hergert, 2009; Khalil, 2015). The intention of the Department of Sport Management is to ensure that internship is a meaningful learning experience which helps students to develop their human capital and this study aims to contribute towards that goal.

\section{Research design and data}

In order to examine the satisfaction of students from the internship program, a questionnaire was developed based on the review of previous literature, after being modified according to the specific requirements and features of the department's internship program (Maynes, et al., 2013). Being more specific, the first three questions were asking about the nature of the placement and the level of cooperation with the host organization. Following the work by Maynes et al. (2013), the following four questions targeted on gaining a perspective on students' beliefs about future employability and career enhancement and whether internship helped them gain experiences and contacts that with help them in their career potential. Finally, the last question probed respondents' beliefs on the importance of the internship program for the completion of their studies (Chambers, 2009). All questions regarding the satisfaction, employability and usefulness of the internship program were assessed and rated from two to three faculty members who were involved with the program and the questionnaire was validated for its consistency and literacy by another faculty member specialized in the field of qualitative research. Finally, five students were employed as pilots 


\section{Macrothink}

Journal of Studies in Education

ISSN 2162-6952

2016, Vol. 6, No. 3

for improving the appropriateness and clarity of the survey. The questionnaire is formed by eight questions and the responses are graded on a 5-point Likert scale ranging from one (1) coded as totally agree to five (5) totally disagree. The questionnaire is presented in the appendix.

Despite the fact that the number of students taking part on the department's internship program varies from year to year, the data analysis from the past indicates that the average number of interns is 98 students per year. The dataset collected for this study is from those students who took part and completed the internship program during the summer of 2015 (July and August). The questionnaire was distributed to the students electronically in their academic e-mail accounts. A cover letter explaining the purpose of the study with an emphasis on their voluntary participation was also sent in that e-mail message. Additionally, the anonymity and confidentiality of responses were also protected and that fact was made clear to all respondents before the completion of the survey. From 98 potential respondents, we collected 49 usable responses for analysis, leading to a response rate of 50 percent, which is quite satisfactory for this kind of studies. The majority of the participant students are male (36 respondents) and the remaining 13 respondents are women.

\section{Results}

The results from the questionnaire respondents are presented in Table 1. As we can see the results show that in general the students perceived the internship organization as adequately to highly cooperative since the majority of the respondents (34.7\%) agreed with the first question. Regarding the second question, the majority of the respondents $(29.2 \%$ agreed and $29.2 \%$ strongly agreed) indicated that their internship was in the field of sport management. This actually indicates a form of recognition of the Department of Sport Management by the sport market place. This means that the sport labor market enhances awareness of what the department and its graduates can offer to their organization. 


\section{Macrothink}

Table 1. Descriptive results of questionnaire respondents

\begin{tabular}{|c|c|c|c|c|c|}
\hline Questions & $\begin{array}{l}1 \text { (totally } \\
\text { disagree) }\end{array}$ & 2 & 3 & 4 & $\begin{array}{l}5 \text { (totally } \\
\text { agree) }\end{array}$ \\
\hline $\begin{array}{l}\text { 1. The host organization } \\
\text { was cooperative }\end{array}$ & $8(16.3 \%)$ & $5(10.2 \%)$ & $12(24.5 \%)$ & $17(34.7 \%)$ & $7(14.3 \%)$ \\
\hline $\begin{array}{l}\text { 2. Your internship was in } \\
\text { the field of sport } \\
\text { management }\end{array}$ & $7(14.6 \%)$ & $8(16.7 \%)$ & $5(10.4 \%)$ & $14(29.2 \%)$ & $14(29.2 \%)$ \\
\hline $\begin{array}{l}\text { 3. The scientific level of } \\
\text { internship was at high } \\
\text { standards }\end{array}$ & $6(12.5 \%)$ & $7(14.6 \%)$ & $20(41.7 \%)$ & $7(14.6 \%)$ & $8(16.7 \%)$ \\
\hline $\begin{array}{l}\text { 4. You are satisfied with } \\
\text { your participation in the } \\
\text { internship program }\end{array}$ & $3(6.4 \%)$ & $4(8.5 \%)$ & $11(23.4 \%)$ & $16(34 \%)$ & $13(27.7 \%)$ \\
\hline $\begin{array}{l}\text { 5. The knowledge you } \\
\text { received from the } \\
\text { Department of Sport } \\
\text { Management proved useful } \\
\text { during your internship }\end{array}$ & $12(24.5 \%)$ & $4(8.2 \%)$ & $16(32.7 \%)$ & $10(20.4 \%)$ & $7(14.3 \%)$ \\
\hline $\begin{array}{l}\text { 6. You gained significant } \\
\text { experiences which will help } \\
\text { you with your future } \\
\text { employment possibilities }\end{array}$ & $4(8.2 \%)$ & $5(10.2 \%)$ & $8(16.3 \%)$ & $17(34.7 \%)$ & $15(30.6 \%)$ \\
\hline $\begin{array}{l}\text { 7. The personal contacts } \\
\text { that you had with } \\
\text { professionals from the host } \\
\text { organization will help you } \\
\text { with your future } \\
\text { employment }\end{array}$ & $4(8.2 \%)$ & $9(18.4 \%)$ & $8(16.3 \%)$ & $23(46.9 \%)$ & $5(10.2 \%)$ \\
\hline $\begin{array}{l}\text { 8. Your participation in the } \\
\text { department's internship } \\
\text { program is important for } \\
\text { the completion of your } \\
\text { studies }\end{array}$ & $3(6.1 \%)$ & $4(8.2 \%)$ & $5(10.2 \%)$ & $13(26.5 \%)$ & $24(49.0 \%)$ \\
\hline
\end{tabular}

Moreover, referring to the third question which regards the scientific level of internship, respondents seem to be divided, with the majority of them $(41.7 \%)$ believing that the scientific level of the internship was mediocre. Nevertheless, most of the respondents $(34 \%$ 
agree and $27.7 \%$ strongly agree) were satisfied with the experience of internship and its potential to help in their future job placement or employment. This response, in conjunction with the responses in questions 6 and 7 (gaining experiences and interpersonal contacts for future employment) where the majority of the students believe that the internship provided them with experiences and personal contacts for future career enhancement are the most significant findings from the study. Students believe that the internship program helped them to sharpen their competences and augment their career potential. This finding corroborates evidence by Maynes et al. (2013) that service learning placement was positively received by participants and host institutions and making service learning an integral part of the educational program. Moreover, findings indicate the intention of students to work in the field of sports and to support the internship program as a key mechanism for providing access to the labor market and an opportunity to demonstrate their abilities and even the feeling of succeeding in the first job upon graduation.

Finally, regarding the fifth question whether students believe that the knowledge that they gained during their studies was useful for their internship, there was a large percentage of respondents (above thirty percent) stating that it was not. However, this outcome cannot only be perceived as an indication that students receive incomplete knowledge during their studies; rather we believe that students were employed in daily tasks that did not require the application of scientific methodologies and theories. Nonetheless, more than $75 \%$ of the respondents agree and strongly agree that internship is a very important feature of the curriculum. This response provides us with the impetus to support and even improve the internship program since it is highly supported by the students as they perceive it as a mechanism that can enhance their career potential.

\section{Conclusion}

The scope of this study was to examine how satisfied the students of the Department of Sport Management of the University of Peloponnese in Greece were, with their internship experience and whether they gained any advantages for their future employability. After the analysis of 50 questionnaires distributed to undergraduate students who completed their internship during the summer of 2015 we found evidence that most of the respondents were satisfied with the experience of internship and believed that it can help them towards their future employment. Additionally, the majority of the students believe that the internship program provided them with useful experiences and personal contacts for future career enhancement. Students believe that the internship program helped them to sharpen their competences and improved their career potential. These findings corroborate arguments by Khalil (2015) and Binder et al. (2015) that internship can improve career potential and employability. Practically undergraduate courses without an internship program carry an academic disadvantage.

The findings of this study could have implications for the directors and designers of internship programs, not only within the University of Peloponnese, but also within other academic institutions. Since students seem to be satisfied with the experiential learning process via their participation in the internship program, it seems that the program itself is 
well organized and structured and achieves its main goals which are the awareness and cohesion of the sport labor market. Also, directors of the internship program can improve the students' assignments to the internship organizations in order to assist students to perform meaningful tasks and implement the knowledge gained from the classroom in their daily work. This improvement may further reduce dissatisfaction responses and achieve greater connection between student and departmental goals.

Nevertheless, this study has a number of limitations that need to be considered in terms of interpretation of the findings and implementation of relative studies in other academic institutions. Firstly, the responses may be influenced by external factors (defensiveness, attitudes, and emotion or negative experiences). This fact can infer bias on the measurement of students' perceptions. Future research can improve the data collection tool by improving the questions towards the learning goals of the internship program. Moreover, since this study is focused on the internship program of the University of Peloponnese, the main findings cannot be generalized to other academic organizations with different goals, structures, objectives and requirements. Thus, future studies can replicate this study and compare the results in order to have definite and generalized conclusions. Furthermore, the sample of the study is rather small, so future endeavors can incorporate a larger sample and even include data on the employer's assessment of students' internship. This fact can provide valuable insights for further improving and revising the internship program (Khalil, 2015).

\section{References}

Alpert, F., Heaney, J., \& Kuhn, K. (2009). Internships in marketing: goals, structures and assessment-student, company and academic perspectives. Australasian Marketing Journal, 17(1), 36-45. http://dx.doi.org/10.1016/j.ausmj.2009.01.003

Andrews, J., \& Higson H. (2008). Graduate employability: soft skills versus hard business knowledge: A European study. Higher Education in Europe, 33(4), 411-422. http://dx.doi.org/10.1080/03797720802522627

Binder, J.F., Baguley, T., Crook, C., \& Miller, F. (2015). The academic value of internship: Benefits across disciplines and student backgrounds. Contemporary Education Psychology, 41, 73-82. http://dx.doi.org/10.1016/j.cedpsych.2014.12.001

Chambers, T. (2009). A continuum of approaches to service-learning within Canadian post-secondary education. Canadian Journal of Higher Education, 39(2), 77-100.

Chambers, T., \& Chiang, C.-H. (2012). Understanding undergraduate students' experience: a content analysis using NSSE open-ended comments as an example. Quality and Quantity, 46, 1113-1123. http://dx.doi.org/10.1007/s11135-011-9549-3

Chen, C., Hu, J., Wang, C., \& Chen, C. (2011). A study of the effects of internship experiences on the behavioural intentions of college students majoring in leisure management in Taiwan. Journal of Hospitality, Leisure, Sport and Tourism Education, 10(2), 61-73. http://dx.doi.org/10.3794/johlste.102.294

Clark, S.C., (2003). Enhancing the educational value of business internships. Journal of 
Management Education, 27(4), 472-484. http://dx.doi.org/10.1177/1052562903251350

Hergert, M. (2009). Students perceptions of the value of internships in business education. American Journal of Business Education, 2(8), 9-13. http://dx.doi.org/10.19030/ajbe.v2i8.4594

Khalil, O.E.M. (2015). Students' experiences with the business internship program at Kuwait University. The International Journal of Management Education, 13, 202-217. http://dx.doi.org/10.1016/j.ijme.2015.05.003

Kipreos, G., \& Dimitropoulos, P. (2013). Internship and employment opportunities: The case of the Department of Sport Management, University of Peloponnese. Conference proceedings on "The internship on the Academic Institutions", Iraklio Crete, Greece 17-18 October 2013, 91-95.

Kwan, F.V.C. (2005). Effect of supervised work experience on perception of work in the tourism and hospitality industry. Journal of Human Resources in Hospitality and Tourism, 4(2), 65-82. http://dx.doi.org/10.1300/J171v04n02_04

Lee, C-S., \& Chao, C-W. (2013). Intention to "leave" or "stay" - The role of internship organization in the improvement of hospitality students' industry employment intentions. Asian Pacific Journal of Tourism Research, 18(7), 749-765. http://dx.doi.org/10.1080/10941665.2012.695290

Maynes, N., Hatt, B., \& Wideman, R. (2013). Service learning as a practicum experience in a pre-service education program. Canadian Journal of Higher Education, 43(1), 80-99.

\section{Appendix}

1. The host organization was cooperative

\begin{tabular}{|c|c|c|c|c|}
\hline $5-$ totally agree & 4 & 3 & 2 & $\begin{array}{c}1-\text { totally } \\
\text { disagree }\end{array}$ \\
\hline
\end{tabular}

2. Your internship was in the field of sport management

\begin{tabular}{|c|c|c|c|c|}
\hline 5 - totally agree & 4 & 3 & 2 & $1-$ totally \\
disagree
\end{tabular}

3. The scientific level of internship was at high standards.

\begin{tabular}{|c|c|c|c|c|}
\hline $5-$ totally agree & 4 & 3 & 2 & $\begin{array}{c}1-\text { totally } \\
\text { disagree }\end{array}$ \\
\hline
\end{tabular}

4. You are satisfied with your participation in the internship program

\begin{tabular}{|c|c|c|c|c|}
\hline $5-$ totally agree & 4 & 3 & 2 & $1-$ totally \\
disagree
\end{tabular}




\section{Macrothink}

Journal of Studies in Education

ISSN 2162-6952

2016, Vol. 6, No. 3

5. The knowledge you received from the Department of Sport Management proved useful during your internship

\begin{tabular}{|c|c|c|c|c|}
\hline 5 - totally agree & 4 & 3 & 2 & $\begin{array}{c}1-\text { totally } \\
\text { disagree }\end{array}$ \\
\hline
\end{tabular}

6. You gained significant experiences which will help you with your future employment possibilities

\begin{tabular}{|c|c|c|c|c|}
\hline $5-$ totally agree & 4 & 3 & 2 & $\begin{array}{c}1-\text { totally } \\
\text { disagree }\end{array}$ \\
\hline
\end{tabular}

7. The personal contacts that you had with professionals from the host organization will help you with your future employment

\begin{tabular}{|c|c|c|c|c|}
\hline $5-$ totally agree & 4 & 3 & 2 & $1-$ totally \\
disagree
\end{tabular}

8. Your participation in the department's internship program is important for the completion of your studies

\begin{tabular}{|c|c|c|c|c|}
\hline $5-$ totally agree & 4 & 3 & 2 & $1-$ totally \\
disagree
\end{tabular}

